IZA DP No. 6984

High-Performance Management Practices and Employee Outcomes in Denmark

Annalisa Cristini

Tor Eriksson

Dario Pozzoli

November 2012 


\title{
High-Performance Management Practices and Employee Outcomes in Denmark
}

\author{
Annalisa Cristini \\ University of Bergamo \\ Tor Eriksson \\ University of Aarhus \\ Dario Pozzoli \\ University of Aarhus and IZA
}
Discussion Paper No. 6984
November 2012

\author{
IZA \\ P.O. Box 7240 \\ 53072 Bonn \\ Germany \\ Phone: +49-228-3894-0 \\ Fax: +49-228-3894-180 \\ E-mail: iza@iza.org
}

\begin{abstract}
Any opinions expressed here are those of the author(s) and not those of IZA. Research published in this series may include views on policy, but the institute itself takes no institutional policy positions. The IZA research network is committed to the IZA Guiding Principles of Research Integrity.

The Institute for the Study of Labor (IZA) in Bonn is a local and virtual international research center and a place of communication between science, politics and business. IZA is an independent nonprofit organization supported by Deutsche Post Foundation. The center is associated with the University of Bonn and offers a stimulating research environment through its international network, workshops and conferences, data service, project support, research visits and doctoral program. IZA engages in (i) original and internationally competitive research in all fields of labor economics, (ii) development of policy concepts, and (iii) dissemination of research results and concepts to the interested public.
\end{abstract}

IZA Discussion Papers often represent preliminary work and are circulated to encourage discussion. Citation of such a paper should account for its provisional character. A revised version may be available directly from the author. 
IZA Discussion Paper No. 6984

November 2012

\section{ABSTRACT}

\section{High-Performance Management Practices and Employee Outcomes in Denmark}

High-performance work practices are frequently considered to have positive effects on corporate performance, but what do they do for employees? After assessing the correlation between organizational innovation and firm performance, this article investigates whether high-involvement work practices affect workers in terms of wages, wage inequality and workforce composition. The analysis is based on a survey directed at Danish firms matched with linked employer-employee data and also examines whether the relationship between high-involvement work practices and employee outcomes is affected by the industrial relations context.

JEL Classification: C33, J41, J53, L20

Keywords: $\quad$ workplace practices, wage inequality, workforce composition, hierarchy

Corresponding author:

Annalisa Cristini

Department of Economics

University of Bergamo

Via dei Caniana 2

24127 Bergamo

Italy

E-mail: annalisa.cristini@unibg.it

\footnotetext{
We thank Michael Rosholm and John Van Reenen for helpful comments and suggestions. In addition, we appreciate comments from participants at the CIM 2009 Workshop in Aarhus and at the 2010 EALE/SOLE conference in London. The usual disclaimer applies.
} 


\section{Introduction}

In recent years, a growing literature has been concerned with the analysis of the characteristics of so-called high-involvement and high-performance work practices (henceforth HPWP) and their impacts on firm performance. The "new work organizations" originate from various intersecting managerial approaches developed in the 1980's and 1990 's, the most prominent of which are the lean production model and Total Quality Management (TQM). Centered on the concepts of employees' involvement, empowerment and autonomy, a typical set of innovative practices includes: self managed teams, job rotation, formal arrangements to discuss production problems (e.g., quality circles), rewards for employees' suggestions, performance related pay and information sharing. According to a number of empirical works, these innovative work systems are associated with higher levels of productivity (Ichniowski, Shaw and Prennushi, 1997; Greenan and Mairesse,1999; Bauer, 2003; Cristini et al., 2003; Zwick and Kuckulenz, 2004). ${ }^{1}$ The channels through which these practices give rise to productivity improvements are, however, not well understood. While some studies have failed to find support of HPWP as productivity enhancers (Freeman et al., 2000; Cappelli and Neumark, 2001; Godard, 2004), others have shown that the mere presence HPWP may not be sufficient to improve the firm's performance and that factors like the lack of a coherent bundle of practices, of complementary ICT investments, of adequate skills and unions' support, may hamper a successful adoption of HPWPs (Osterman, 1994; Black and Lynch, 1998; Bresnahan, Brynjolfsson and Hitt, 2002). Furthermore, many of those who have recently reviewed the available empirical literature (Paauwe and Boselie, 2005; Wood and Wall, 2007; Bloom and van Reenen, 2010) have come to the conclusion that the evidence is only suggestive. In particular, and this is the focus in the current paper, the

\footnotetext{
${ }^{1}$ The existing empirical evidence is based either on case studies or on cross-sectional data; evidence using more comprehensive data is fairly scarce. Exceptions are e.g., Black et al. (2004) and Kalmi and Kauhanen (2008).
} 
ways employee outcomes contribute to the productivity effects of HPWP have received relatively little attention, thereby leaving some fundamental questions unanswered.

First of all, there is no consensus as to the extent to which employees gain financially from HPWP. ${ }^{2}$ This may reflect the "a priori" theoretical ambiguity as HPWP may have opposite impacts on wages (Handel and Levine, 2004). On the one hand, a positive relationship between pay and high-involvement management may arise if HPWP improve the firm's performance and employees can seize some of the higher rent created. A related rationale is the efficiency wage argument; in particular, a pecuniary reward may be used to overcome resistance to change. Supervisors, for example, may be paid a wage premium to ensure that they do not undermine organizational innovations, which specifically require them to act as facilitators of groups engaged in problem solving; otherwise, these employees' groups may be viewed as a challenge to the authority and job security of a supervisor (Black et al., 2004). Selection effects may also play a decisive role: firm average wages could rise with HPWP adoption in case HPWP jobs are more suited to higher-skilled workers, i.e. those with above-average problem-solving and communication skills. Such workers may select HPWP jobs or firms may actively select them. On the other hand, according to the theory of compensating wage differentials, high-involvement management is expected to be negatively correlated with pay as the latter can be traded off against intrinsically more rewarding jobs created by the high involvement approach.

Secondly, the impact of organizational innovation on within-firm wage inequality

\footnotetext{
${ }^{2}$ On the basis of a nationally representative sample of US establishments, Osterman $(2000,2006)$ finds that the introduction of high performance work systems is positively associated only with the wages of core blue collar manufacturing employees. Cappelli and Neumark (2001), using the Educational Quality of the Workforce National Employer Survey (EQW-NES), find that some workplace practices, specifically benchmarking and total quality management, are positively related to average labour costs per worker. Handel and Gittleman (2000) and Black, Lynch and Krivelyova (2004) find no wage impact of HPWP.
} 
has only been examined in a few studies. Again, the existing evidence is ambiguous (Aghion, Caroli and Garcia-Penalosa, 1999) and mirrors a theoretical ambiguous relationship. On the one hand, the fact that HPWP are "skill biased" and associated with a lower relative demand and higher layoff rates of unskilled production workers (Caroli and van Reenen 2001; Osterman 2000; Black, Lynch, and Krivelyova, 2004) is the main reason for expecting organizational changes to be negatively correlated with wage inequality. This is especially the case, if the overall dispersion of skill levels within the firm becomes narrower. As long as organizational changes imply delegation of decision rights to lower layers in the hierarchy, incentive considerations and skill upgrading through training may lead to wage increases in the lower part of the occupational structure, thereby narrowing wage inequality within firms. Inequality would increase, however, if the very low-skilled were retained and not retrained and HPWP jobs were filled by newly-retrained moderately-skilled workers.

Thirdly, the presence of unions has an ambiguous effect both on the probability of adoption and the cost of adopting HPWP (Machin and Wood, 2005). This has been investigated only by a few studies. Using a British survey, Forth and Millward (2004) show that high-involvement management is associated with higher pay and that the high-involvement management premium is higher where unions are involved in effective pay bargaining. Godard (2007) finds that innovative work practices are associated with meaningful pay gains for union workers in both Canada and England. However, as the data used in both studies are cross-sectional, it is not possible to say whether a causal relationship exists. Black, Lynch and Krivelyova (2004) partly address the issue of endogeneity working with a small panel of US manufacturing establishments and find a significant effect of HPWP on wages and wage inequality among unionized employers only. A key feature of the Danish industrial relations is the little relevance of the national legislation in the functioning of labour market: contrary to most other 
European countries, rules and regulations are often the result of a close cooperation between employers' organizations and trade unions. Thus, for instance, working environment, including job safety, employment protection and normal working hours are, to a high extent, the result of negotiations between labour market parties. ${ }^{3}$, likewise, unions are generally supportive of innovative work practices and their introduction is usually preceded by discussions and negotiations between the firm and its employees' representatives. Given this active role of Danish unions in the design and implementation of work practices, we don't expect unions to have a further mediation on the effects of HPWP. ${ }^{4}$

In this paper, we use a unique 1999 survey $^{5}$ on work practices of Danish private sector firms merged to a large matched employer-employee dataset, which provides us with a wide collection of information on firm characteristics. Our dataset allows us to overcome some limitations of the previous studies and sheds some light on unexplored research questions. In particular, this paper contributes to the literature in several ways.

First of all, it is the first comprehensive study on the effects of organizational innovation, considering both firm performance and employees' welfare as relevant outcomes. After exploring the relationship between high-performance work practices and firm productivity, we also examine how organizational changes affect workers in terms of wages, wage inequality and workforce composition.

\footnotetext{
${ }^{3} \mathrm{~A}$ difference between the Danish institutional structure and those of many other countries is the absence of the minimum wage legislation which is, instead, negotiated by the social partners. Industrial conflicts are also remarkably rare in Denmark (Westergaard-Nielsen, 2001)

${ }^{4}$ Notice that cooperative unions may also help employers retain employees, a key point for the success of high involvement practices for which employees' specific human capital is an essential contribution to the firm productivity (Freeman and Medoff, 1984)

${ }^{5}$ A corresponding survey carried out in 2009 shows that use of all the HPWPs examined in this paper has spread to a larger proportion of firms; see Eriksson (2011). Unfortunately, the data on firm performance (and other variables coming from the administrative registers) are not yet available.
} 
Secondly, the longitudinal dimension of the register data enables us to estimate the association between workplace practices and firm and employee outcomes, controlling both for time-invariant unobserved heterogeneity and for time varying variables which are not accounted for in cross section surveys. Neglecting unobserved fixed effects or time varying regressors, could bias the "true effect" of practices on firm performance and wages (Bloom and Van Reenen, 2007). For example, if the firm's decisions to adopt workplace practices are related to their business performance and the firm decides to introduce organizational innovation in a troublesome period (Nickell et al., 1997), then the cross-sectional estimated effect on productivity would be biased downward. However, the latter would be biased upward if, instead, employers are more likely to adopt new workplace practices when times are good. To address these potential biases, we first obtain estimates of the coefficients of the time-varying variables using a fixedeffects estimator and then regress the average residuals on an index of organizational innovation in the second stage (Black and Lynch, 2001). Additionally, we also calculate the same effects in one step, using a fixed effect estimator, for a subset of practices for which we can exploit the longitudinal information.

Last but not least, the possibility to more precisely measure relevant workforce composition characteristics allows us to examine potential omitted variables biases and to get closer to the true "average" effect of organizational innovation on the overall firmlevel performance. Specifically a big advantage of this study is the ability to control for human capital attributes. In the previous literature, a typical concern about HPWS results has, in fact, been to what extent HPWS require more skilled workers and, in turn, to what extent those skills, typically unmeasured, are actually driving the results.

According to our results organizational change is only weakly associated with firm 
level productivity and employers do appear to reward their workers for engaging in high-performance workplace practices. We also find a significant association between organizational innovation and wage inequality, as managers get a higher wage premium compared to non managerial workers. At the same time, high-performance management practices are found to be associated with both a drop of the managerial employment share and a loss of managerial jobs. Finally, we do not find significant differences in the effects of HPWP between unionized and non unionized firms.

The structure of the remainder of the paper is as follows. The data are described in detail in Section 2. Section 3 presents the estimation strategy. Section 4 presents and discusses the findings and Section 5 concludes.

\section{Data}

The data set contains information about Danish private sector firms with more than 20 employees and has been constructed by merging information from two different sources. The first source is a questionnaire directed at firms that contain information about their work and compensation practices. ${ }^{6}$ The survey was administered by Statistics Denmark as a mail questionnaire survey in May and June 1999 and was sent out to 3,200 private sector firms with more than 20 employees. The firms were chosen from a random sample, stratified according to size (as measured by the number of full time employees) and industry. ${ }^{7}$ The survey over-sampled large and medium-sized firms: it included all firms with 50 or more employees and 35 per cent of firms in the 20-49 employees range. The response rate was 51 per cent, which is relatively high

\footnotetext{
${ }^{6} \mathrm{~A}$ description of the questionnaire and the main results are given in Eriksson (2001).

${ }^{7}$ In the final sample, $46 \%$ of firms belong to the manufacturing sector, $10 \%$ to the construction sector, $32 \%$ to the wholesale trade sector, $4 \%$ to the transport sector and $8 \%$ to the financial sector.
} 
for the rather long and detailed questionnaire that was used. ${ }^{8}$ The survey represents a unique source of information on Danish firms' internal labour markets and changes therein. In addition to some background information, each firm was asked about its work organization, compensation systems, recruitment, internal training practices, and employee performance evaluation. As for work design and practices, firms were asked to differentiate salaried from non managerial employees.

The second data source is the "Integrated Database for labour Market Research" (IDA henceforth) provided by Denmark Statistics. IDA is a longitudinal employeremployee register containing relevant information (age, demographic characteristics, education, labour market experience, tenure and earnings) on individuals employed in the recorded population of Danish firms during the period 1995-1999. Apart from deaths and permanent migration, there is no attrition in the dataset. The labour market status of each person is recorded at the 30th of November each year. The retrieved information has been aggregated at the level of the firm to obtain information on the workforce composition (i.e. proportion of men, skilled employees, managers, middle managers, non managerial workers, and the proportion of employees with different tenure and age) and the mean and variance of the hourly wage. ${ }^{9}$ Additional variables, collected from firm registers (REGNSKAB henceforth), are size, geographical location, industry and a set of financial items for the years 1995 to 1999, i.e. the value of intermediate goods or materials, fixed assets, and value added. ${ }^{10}$ On one hand, our

\footnotetext{
${ }^{8}$ We take account of the sample design used for the survey by using the sampling weights provided in the data-set; these weights being approximately equal to the inverse of the probability of selection of each firm into the sample. The response rates by size and one-digit industry cells vary only between 47 and 53 per cent. However, given that half of all eligible respondents refused to take part, there may be a reasonable chance of response bias: struggling firms may be less likely to give time to complete surveys compared to well performing firms. We can, though, in part dismiss such possibility as the distributions of firm value added for the group of respondents and non respondents are remarkably similar (results are available on request from the authors).

${ }^{9}$ For the empirical specification where we use different time periods, we deflate wages with the consumer price index using 2000 as the base year.

${ }^{10}$ We face some unavoidable sample reduction during the merging procedure. Merging the survey
} 
two steps estimation procedure, explained in the next section, requires to restrict the analysis to the years 1997 to 1999, a compromise between having a sufficiently large number of years to identify the firm fixed effects and a short enough time period to avoid too much variation in the adoption of work practices. ${ }^{11}$ On the other, the one step approach, based on the time variation of practices for which the exact year of adoption is available, demands a longer time period. To make the results obtained from both approaches comparable with each other, we run all these models for both a general sample, from 1995 to 1999, and a restricted one, from 1997 to 1999.

Table 1 reports means and standard deviations of the variables of interest. At the bottom of the table, we also report the mean and standard deviation of the variables drawn from the survey, such as the dummy variable "unions". ${ }^{12}$

\subsection{Variables}

The survey distinguishes between a few specific innovative practices: employees' involvement in self-managed teams, job rotation, quality circles, total quality management, benchmarking, project organization, financial participation schemes and on the job training. ${ }^{13}$ Except for training programs and different financial participation to REGNSKAB (IDA) reduces the sample of 254 (12) firms, leaving us with a final sample of 1349 firms. This loss of information does not harm the representativeness of the final sample.

${ }^{11}$ Table 2 indicates that most practices have been in use for more than three years, which suggests that the triennium 1997-1999 is a likely period for HPWP not to change much. The figures reported in table 2, however, report a change only one direction, i.e. recent adoption. The survey gives, in fact, no insight into the rates of cessation. Quality circles, in particular, may sometimes be only temporary arrangements and abandoned once process improvements have been identified and implemented. A recent survey in 2009, though, shows that the rates of adoption have increased over the course of the last decade.

${ }^{12}$ We capture the presence of the unions by looking at whether the firm has a local collective agreement concerning wages and working hours for all employees. Note that union membership is internationally high in Denmark, as over 80 per cent of wage earners are trade union members. So the measure we use in this paper is picking up strong presence of unions at the workplace level.

${ }^{13}$ Appendix A reports a detailed list of questions extracted from the survey used to define these workplace practices. 
schemes ${ }^{14}$, the survey also asked when each practice was first adopted. Table 2 provides an overview of the diffusion of the practices. Training and financial participation schemes are the most diffused practices, involving more than $50 \%$ of firms. Team working is also relatively prevalent $(21.54 \%)$, while project organization and job rotation is used in about $15 \%$ of the firms. Finally, only a small fraction of Danish firms offer some form of employee involvement through quality circles (2.6\%), benchmarking (3.77\%) and total quality management $(4.52 \%)$.

The least diffused practices, such as benchmarking and total quality management, have been in place for a shorter period than more diffused practices - like self-managed teams and project organization. Even though this may sometimes indicate waves of interest or management fads, one realistic economic interpretation is that firms introduce organizational innovation gradually and that a sequential ordering of the practices may exist so that some practices form the basis to others leading to the most advanced innovative systems, as already documented by Freeman et al. (2000). Consequently it is plausible that the number of practices adopted can serve as a proxy for the intensity of implementation. Hence, our main measure of organizational innovation is a single additive index of organizational innovation constructed as the sum of all HPWPs implemented by the firm. On average in 1999 firms adopted 1.9 practices out of 8; however, if we exclude training and financial performance, the count index in 1999 drops to 0.69 thus confirming the prominent role of the two excluded practices; the count index of the six practices slightly increased between 1995 and 1999 moving from 0.49 in 1995 to 0.71 in $1999 .{ }^{15}$ We consider four outcomes: (1) the log of the

\footnotetext{
${ }^{14}$ The questionnaire only asked firms whether they made substantial changes in their payment systems in recent years, without being more specific as to when or to which payment system. Also, there is no information regarding the proportion of employees involved in a particular work design.

${ }^{15}$ The restricted count index computed for the six practices for which the longitudinal information is available will be used to perform one-step longitudinal estimates to be compared with the usual twostep estimates. We also calculated two alternative indexes to measure the intensity of implementation. The first one is a weighted count index, the weights being the difficulty parameters estimated from
} 
firm value added; (2) the log of the firm average hourly wage, overall and by three occupational groups (managers, middle managers and non managerial workers); (3) the within firm wage inequality measured, alternatively, as: i) the ratio of the average firm wage of managers to the average wage of non managerial workers, ii) the ratio of the 90 th percentile to the 10 th percentile, iii) the ratio of the 90 th percentile to the 50th percentile and iv) the ratio of the 50th percentile to the 10 th percentile of the wage distribution; (4) the workforce composition measured by the proportions of managers, middle managers and non managerial workers of all employees in the firm.

Table 3 reports the means of the outcome variables by the number of HPWP adopted. We may notice that both the firm financial performance and the wage inequality measured by the proportion of managers' average wage and blue collars' average wage rise with the number of practices adopted. The average hourly wage, the wage of managers and middle managers and the firm's share of managers and middle managers as a proportion of all employees also rise with the intensity of organizational innovation. However, the relation turns negative for a number of practices grater than 4 , suggesting the presence of non-linearities.

the Rasch analysis (for more details, see Freeman et al., 2000). The difficulty parameters associated with each practice indicates that the most widely diffused practices are also the easiest to adopt. This confirms the hypothesis that workplace practices are adopted along an increasingly sequential path where the easiest practices are the first ones to be introduced, followed by more difficult ones. The second index is obtained from principal component analysis. Results, obtained using these alternative indices, are highly similar to the ones reported in section 4 and are available on request from the authors. 


\section{$3 \quad$ Empirical Strategy}

\subsection{Impact of organizational innovation on firm performance}

In order to relate the firm's total factor productivity to the workplace practices, we use a two step procedure (Black and Lynch, 2001) according to which TFP is first estimated using panel information and, in the second step, the estimated time average TFP is related to the cross-sectional measure of HPWP. The use of panel information in the first step, coupled with a structural identification of the production function parameters in accordance with the algorithm proposed by Wooldridge (2009), allows us to control for the unobservable firm characteristics and cope with both endogeneity issues and potential measurement errors. Additionally, we also calculate the same effects in one step, using a fixed effect estimator, for a subset of practices for which we can exploit the longitudinal information, as we have mentioned in the introduction.

\subsubsection{Two steps approach}

In the first stage of the estimation procedure, the empirical specification of the production function is given by:

$$
y_{i t}=\beta_{0}+\beta_{l} l_{i t}+\beta_{k} k_{i t}+\beta_{c} C_{i t}+u_{i t},
$$

where the dependent variable $y$ is the $\log$ of the real value added, $l$ is the $\log$ of labour, $k$ is the log of capital stock, $C$ is a vector of controls including firm specific employee characteristics, whether the firm is foreign owned, firm age and a full set of size, industry, year and regional dummies. The error term $u_{i t}$ consists of a time-varying firm specific effect $v_{i t}$ (unobserved by econometricians) and an idiosyncratic component $\varepsilon_{i t}$. As pointed out by the literature on the identification of firm production functions, the major issue in the estimation of parameters is the possibility that factors influencing 
production are unobserved by the researcher but observed by the firm. Specifically, firms are expected to respond to positive (negative) productivity shocks by expanding (reducing) output, which requires higher (smaller) quantity/quality of intermediate inputs and materials. Ackerberg, Caves and Frazer (2006) (ACF henceforth) build upon Olley and Peakes (1996) and Levinsohn and Petrin (2003) to develop a methodology that addresses the issues of individual effects and of the productivity components' endogeneity and autocorrelation. The way these issues are tackled is quite different from the GMM approach. While the system GMM framework requires a long time span, since lagged values and differences are used as instruments ${ }^{16}$, ACF make use of proxies for productivity, which are modeled as first-order Markov process. Wooldrige (2009) suggests that the ACF approach is readily practicable in a one step framework. Having only a short period of time and given the discussion above, Wooldridge (2009) is our preferred estimation approach to estimate equation (1). Specifically, we assume that

$$
E\left(\varepsilon_{i t} \mid l_{i t}, k_{i t}, m_{i t}, l_{i t-1}, k_{i t-1,}, m_{i t-1}, \ldots, l_{i 1}, k_{i 1}, m_{i 1}\right)=0,
$$

with $\mathrm{t}=1,2, \ldots, \mathrm{T}$, and where $m$ refers to our proxy variable (materials). For the sake of simplicity, we do not include the vector of control variables $C$ among our production inputs. As past values of $\varepsilon_{i t}$ are not included in the conditioning set, it means that we allow for serial dependence in the pure shock term. However, we need to restrict the dynamics in the productivity process, $v_{i t}$ :

$$
E\left(v_{i t} \mid v_{i t-1}, v_{i t-2}, \ldots, v_{i 1}\right)=E\left(v_{i t} \mid v_{i t-1}\right)=f\left(v_{i t-1}\right)=f\left[g\left(k_{i t-1}, m_{i t-1}\right)\right]
$$

\footnotetext{
${ }^{16}$ The GMM system estimator due to Blundell and Bond (2000) tries to solve the endogeneity problem by instrumental variables. In practice, the presence of weak instruments is quite frequent.
} 
with $\mathrm{t}=1,2, \ldots, \mathrm{T}$ and for given functions $f(\cdot)$ and $g(\cdot, \cdot)$. Furthermore, it is imposed that

$$
E\left(a_{i t} \mid k_{i t}, k_{i t-1}, l_{i t-1}, m_{i t-1}, \ldots, k_{i 1}, l_{i 1}, m_{i 1}\right)=0
$$

with $a_{i t}=v_{i t}-E\left(v_{i t} \mid v_{i t-1}\right)$. The latter equation implies that the innovation $a_{i t}$ can be correlated with current values of the proxy variable $m_{i t}$ and variable inputs $l_{i t}$. Following the Levinsohn and Petrin (2003) approach, we approximate $f(\cdot)$ and $g(\cdot, \cdot)$ by low-degree polynomials in dependent variables. Thus, we can use the contemporaneous state variable $k_{i t}$, lagged inputs and functions of these as instruments $Z$ for a GMM efficient estimation of parameters $\beta_{l}$ and $\beta_{k}{ }^{17}$

The second stage dependent variable is a time period average of the TFP obtained, for each firm, using the production function parameters estimated in the first step. The second step finally relates each firm average TFP to the firm's index of organizational innovation and union dummy:

$$
\overline{\mathrm{TFP}}_{i}=c_{0}+\beta_{1}(\text { index })+\beta_{2}(\text { unions })+\gamma_{r}+\gamma_{j}+\xi
$$

where $\overline{\mathrm{TFP}}_{i}$ is the period average TFP, index is our count measure of organizational innovation, unions is the dummy variable related to the presence of the unions, $\gamma_{r}$ and $\gamma_{j}$ are regional and industry controls.

\subsubsection{One step approach}

Although the two-step procedure extracts the unobserved fixed effect, other biases may still arise in the second step due to the correlations of the second-stage regressors with either/both unobserved, time-invariant, firm-level characteristics or/and the average

\footnotetext{
${ }^{17}$ We would like to thank Amil Petrin for graciously providing us his Stata programme to implement Wooldridge's algorithm.
} 
idiosyncratic shocks because the time period over which we average is relatively short. As we have information on the year of adoption for a subset of practices $^{18}$, we can examine how the time variation of workplace practices is related to changes in productivity. We do this by estimating a more general specification of equation (1):

$$
y_{i t}=\beta_{0}+\beta_{l} l_{i t}+\beta_{k} k_{i t}+\beta_{c} C_{i t}+\beta_{I}(\text { index })_{i t}+u_{i t},
$$

where index is the organizational index for a subset of practices for which we have the exact year of adoption. Like labour input, the count index is also now treated as an endogenous dynamic input and instrumented using its first lag.

\subsection{Impact of organizational innovation on employee outcomes}

The empirical analysis proceeds by looking at the impact of organizational innovation on: mean hourly wages, wage inequality and workforce composition. These employees' outcomes are obtained from the longitudinal register data, averaging over employees' outcomes at the firm level. Again, we implement a two-step strategy; analogously to the previous subsection the first and the second step regressions are specified as follows:

$$
\begin{aligned}
w_{i t} & =\alpha_{0}+\alpha_{1} X_{i t}+u_{i t} \\
\bar{\omega} & =c_{1}+\alpha_{1}(\text { index })+\alpha_{2}(\text { unions })+\gamma_{r}+\gamma_{j}+\xi
\end{aligned}
$$

\footnotetext{
${ }^{18}$ The subset excludes financial participation schemes and training.
} 
where $w_{i t}$ is, alternatively, one of the employees' outcomes, $X$ is a vector of firm specific characteristics, $\omega=w_{i t}-\hat{\alpha_{0}}-\hat{\alpha_{x}} X_{i t}$ is the fixed component of the residual retrieved from the first step, $\bar{\omega}$ is its time period average, and the remaining variables are as previously defined.

Again, as unobserved heterogeneity can potentially affect the estimates, we exploit the panel component of the data to estimate an alternative one step fixed effect regression:

$$
w_{i t}=\alpha_{0}+\alpha_{1} X_{i t}+\alpha_{I}(\text { index })_{i t}+u_{i t}
$$

\section{Results}

This section reports the main findings for each outcome, i.e. productivity, wages, wage inequality and workforce composition, and for two time periods, either from 1997 to 1999 or from 1995 to 1999.

\subsection{Financial performance}

The first three columns of Table 4 shows the results for the two step procedure, described in section 3, using a restricted period from 1997 to 1999. From the first stage, reported in the first column, labour and capital elasticities are respectively 0.777 and 0.088, as in previous studies (Parrotta and Pozzoli, 2012). As far as the workforce characteristics are concerned, the proportion of employees with a tertiary and secondary education and the proportion of men are all statistically significant and carry a positive sign. The results also show that productivity is lower the higher proportion of workers 
with low tenure. When we examine the impact of HPWP on productivity in the second step, reported in the lower panel of the same table, we find that the count index is positively associated with total factor productivity, suggesting that organizational innovation contributes to enhance firm performance. More specifically, a unit increase in the number of practices implies a $1.2 \%$ rise in the average total factor productivity. We also find that productivity is $2.2 \%$ higher in firms with a strong presence of unions, indicating the significant role of the latter and the cooperative attitude of the Danish industrial relations. Not surprisingly, the interaction between the union dummy and the index of organizational innovation is not statistically significant implying that unions do not mediate the effect of HPWP on productivity. This is an intriguing result which highlights the difference with the Anglo-Saxon context where unions affect productivity only via HPWP (Godard 2007, Black Lynch and Krivelyova 2004, Forth and Millward 2004). A final specification for the second step regression replaces the count index with the individual practices. Four practices turn out to be driving the positive effect of the count index: benchmarking, financial performance, job rotation and project organization. Renowned practices like TQM, quality circles and self managed team working, as well as training do not contribute significantly to increase productivity. In fact, teams have a negative effect which is significant at the ten percent level. This has also been found in other studies (Eriksson and Smith, 2007; Cristini, 2011), and suggests that the negative free-rider effect dominate eventual positive impacts when the use of self-managed teams becomes widespread. Almost identical results are obtained by considering a sample which also includes the years 1995 and 1996 (Table 5).

Results obtained from the one-step estimation method (equation 3), described in section 3, are reported in columns 4 and 5 of Tables 4 and 5. A lower and statistically insignificant coefficient is now estimated for the number of practices adopted and none of coefficients of the individual practices are precisely estimated, no matter the sample 
period considered. These results suggest that the significance of organizational innovation in the two steps procedure reported in the first three columns may have been driven by unobserved qualities of the firms. Moreover we cannot rule out that this result is also related to the fact that two essential practices, i.e. financial participation schemes and training, are excluded from the analysis. Finally, there is also clearly the potential for measurement error in the time varying count index as it only identifies adoption and not cessation. Estimating the second step with a specification where each practice is, sequentially, excluded from the count index indicates that the coefficient on the count index does not change when excluding training and it almost halves when excluding financial performance, though remaining highly significant. ${ }^{19}$ Hence, we can argue that what drives the coefficient of the restricted index to zero is either the measurement error or the correlation with some firm fixed factor which are now controlled for. Therefore the results are, on the whole, inconclusive with regard to the relationship between firms' TFP and an overall extensive measure of the adoption of innovative workplace practices.

\subsection{Wages}

Next we investigate whether innovative firms compensate employees for their increased involvement in the production process and for incurring the risk associated with financial participation schemes. Equation 5 is estimated using, alternatively, the log of the average hourly wage both at the firm level and by three main occupation groups (managers, middle managers, non-managerial workers) as dependent variable and for two time periods. The first six columns of Tables 6 and 7 present estimates from the two-stages approach, respectively for the sample between 1997 and 1999 and for the one from 1995 to 1999. The relationships are qualitatively close to those obtained when estimating the association between organizational innovation and productivity. A unit

\footnotetext{
${ }^{19}$ These additional results are available on request from the authors.
} 
increase in the number of practices is associated with approximately $0.8(1.1) \%$ increase in the average wage, when the 1997(1995)-1999 time period is considered in the first step. ${ }^{20}$ If we examine the average wage in each firm by occupation group, we find that results are relatively similar across occupations. However, it seems that the pay of top managers is more affected than the pay of middle-management and non-managerial workers; the difference is relevant: managers gain 1.8-2\% wage increase by a unit increase in the count index while non managerial workers gain $0.5-0.6 \%$ wage increase, depending on the sample used for the first step. These results are consistent with the notion that innovative practices increase the demands on managers, as they are responsible for organizing the other workers and providing an environment conducive to their participation in decision making (Black et al. 2004). As in earlier studies on Danish data (see e.g., Buhai et al., 2008) we find that higher average education, higher proportion of male employees and of managers in the firm are associated with higher average wages. A strong presence of unions, on the contrary, reduce the average wage by approximately $3 \%$; however this appears to be due to the dampening role that unions exercise on managerial and middle-management wages. The interaction between unions and HPWP is also negative but not significant at conventional levels. The positive wage effect of HPWP appears to be driven by training and self managed teams (Column 3 of both Tables 5 and 6 ), which is at odds with the role of HPWP on firms' financial performance. ${ }^{21}$

All in all, these results suggest that managers relative to non-managerial workers, are paid a wage premium to work in an HPWP environment; unlike Black et al. (2004),

\footnotetext{
${ }^{20}$ Very similar estimates are obtained when wage and productivity are simultaneously estimated using a seemingly unrelated regressions model. Results are available on request from the authors.

${ }^{21}$ Results indicate that the formation of the productivity gains, on the one hand, and their distribution, on the other, do not relate to the same practices. To explore the issue, information on the distribution of HPWP by main occupational groups would have been useful but is unfortunately not available.
} 
Forth and Millward (2004) and Godard (2007) we find that a strong presence of unions in innovative workplaces does not provide additional wage increases to employees, i.e. cooperative unions do not seem to mediate for workers' extra gains.

Results from the one step fixed effect approach are reported in the last 5 columns of Tables 6 and 7. For both sample periods, the association between organizational innovation and wages gets weaker and even statistically insignificant for most of the individual practices separately considered. However, contrary to the productivity regression, the coefficient of the count index remains statistically significant, confirming that the pay of managers and middle managers is higher when they are working in a firm with some form of HPWP while the pay of production workers is affected to a smaller extent.

Thus, results show that HPWP concur to rise the average firm wage, albeit the increase is not equal across occupational categories and may not be supported by productivity gains.

\subsection{Wage inequality}

In order to investigate whether organizational innovation increases within firm wage inequality, we consider three measures: i) the ratio of the average wage of managers in a firm to the average wage of non-managerial workers in a firm, ii) the ratio of the 90th percentile to the 10 th or the 50 th percentile and iii) the ratio of the 50 th percentile to the 10th percentile of the wage distribution. Tables 8 and 9 present results from the two-stages and the longitudinal approach, respectively for the period either excluding or including the years 1995 and 1996 in the analysis. All findings from the two-stages approach suggest that a higher number of workplace practices increases within-firm wage inequality: for example, an additional HPWP is associated with a slightly larger gap (around 1-1.6\%, depending on the sample used in the first step) between the aver- 
age wage of managers and of non-managerial workers. Alternative definitions of wage inequality suggest that inequality rises more in the upper part of the distribution, confirming, once more, that managers' pay is affected disproportionately more than that of other employees. Unions' presence shows a negative coefficient and is statistically significant in the decile ratio measures but not in the ratio of managerial to non managerial wage. Training and TQM are the practices that most impact on wage inequality. As far as the main controls are concerned, the proportion of middle managers and workers with a tenure of at least 10 years are positively correlated with wage inequality.

Results are, again, less robust when a one-step fixed effect approach is implemented, especially if we exclude the years 1995 and 1996 from the analysis. Except for the ratio of the average wage of managers to the average wage of non managerial workers, for which the estimated count index coefficient is precisely estimated, the correlation between the count index and all the remaining inequality measures loses all its significance and even its sign changes. It appears that the estimated relationship between workplace innovation and within firm wage inequality is overall fragile, as it is highly sensitive to how inequality is measured and to which estimation method is implemented.

\subsection{Workforce composition}

Finally, to investigate whether innovative practices have any bearing on the firm workforce composition, we estimate equation 5 using the firm level proportion of managers, middle managers and non-managerial workers as dependent variable. The results from both econometric approaches and samples are given in Tables 10-13. In terms of the relationship between organizational innovation and workforce composition, there are two findings worth noting. Innovative workplaces have a lower share of middle managers and a higher share of non-managerial workers, no matter which methodological 
approach is implemented or which time period is considered..$^{22}$ By replacing the count index with the single practices, TQM and, to a lesser extent, job rotation are found to reduce the proportion of hourly paid workers. These results confirm the idea that some workplace practices are skill biased, i.e. they are associated with lower relative demand for unskilled production workers (Caroli and van Reenen 2001; Osterman 2000). Other practices however, namely training and benchmarking tend to increase the share of the hourly paid and reduce that of mid managers. Similar results are obtained from the one step longitudinal approach. On the whole, the estimates are consistent with the hypothesis that organizational innovation is associated with a loss of managerial jobs (Osterman 2000), i.e. HPWP flatten the organizational hierarchy and hence reduce the number of employees at middle managerial levels. ${ }^{23}$

\section{Conclusions}

Integrating existing research on firm organizational structure and performance, this paper analyzes how the adoption of new workplace practices correlates with several firm and employee level outcomes. The analysis presented here offers several advantages over prior efforts to examine the relationship between organizational innovation and organizational outcomes. Most importantly, the availability of detailed firm-level measures together with the longitudinal nature of our data, allow to controlling for heterogeneity, thus significantly improving on prior studies relying on cross-sectional data.

The diffusion of new practices in the Danish private firms is found to vary widely depending on the type of practice: while over $50 \%$ of firms provide employees with

\footnotetext{
${ }^{22}$ Similar results are obtained when the outcome variables are measured in terms of employment numbers instead of shares. The latter are available on request from the authors.

${ }^{23}$ For evidence of flattening hierarchies and a discussion of possible causal factors thereof, see Rajan and Wulf (2010).
} 
training and financial participation schemes, less than a fourth has employees working in self managed teams, only $6 \%$ of firms follow a TQM approach and only $3 \%$ involves employees in quality circles. According to this picture, comprehensive innovative work systems were still quite uncommon in Denmark at the time of this survey, as was the case in most European countries. Nonetheless, the econometric evidence supports significant relations between some outcomes relevant to the workers and the extent of adoption of HPWP. In particular, a unit increase in the count of practices rises the average hourly wage in the range of $1 \%-2 \%$. Given the weak association between practices and TFP this reward is likely attributable not to a sharing of an extra rent gained thanks to these practices, but to considerations related either/both to the risks of financial participation and layoffs or/and to resistance to change type of conducts; both cases call for some form of pecuniary compensation. Our analysis also shows that managers are those that mostly benefit in terms of wages and that middle managers are those most likely to face reduced employment opportunities as a consequence of flatter hierarchies in the workplace. These results suggest that the adoption of HPWP has affected the job hierarchy in firms more than the firms' wage structures. Finally, given the cooperative attitude of Danish trade unions, and contrary to the evidence provided for the Anglo-Saxon context, we do not find that in innovative workplaces a strong presence of unions provides additional gains in terms of both firm and employee level outcomes. 


\section{References}

[1] Ackerberg, D. A., Caves K. and Frazer G. (2006), "Structural Identification of Production Functions," Unpublished manuscript.

[2] Aghion, P., Caroli E. and Garcia-Penalosa C. (1999), "Inequality and Economic Growth: The Perspective of the New Growth Theories," Journal of Economic Literature, 37(4), 1615-1660.

[3] Bauer, T.K. (2003), "Flexible Workplace Practices", IZA Discussion Paper No. 700, Bonn

[4] Black S. and Lynch L. (1998), "Beyond the Incidence of Employer-provided Training," Industrial and labour Relations Review, 52(1), 64-81.

[5] Black, S. and Lynch L. (2001), "How to Compete: the Impact of Workplace Practices and Information Technology on Productivity", Review of Economics and Statistics, 83(3), 434-445.

[6] Black, S., Lynch, L. and Krivelyova, A. (2004), "How Workers Fare When Employers Innovate", Industrial Relations: A Journal of Economy and Society, 43, 1, $44-66$.

[7] Bloom N. and Van Reenen J., (2007), "Measuring and Explaining Management Practices Across Firms and Countries," The Quarterly Journal of Economics, MIT Press, 122(4), 1351-1408.

[8] Bloom N. \& Van Reenen J. , (2010), "Human Resource Management and Productivity," NBER Working Papers 16019, National Bureau of Economic Research, Inc., IN HANDBOOK OF labour ECONOMIUCS VOL 4, 2011.

[9] Blundell R. and Bond S. (2000), "GMM Estimation with Persistent Panel Data: An Application to Production Functions," Econometric Review, 19, 321-340. 
[10] Bresnahan T., Brynjolfsson E. and Hitt L. (2002), "Information Technology, Workplace Organization, And The Demand For Skilled labour: Firm-Level Evidence," The Quarterly Journal of Economics, 117(1), 339-376.

[11] Buhai S., Cottini E. \& Westergaard-Nielsen N. (2008), "The Impact of Workplace Conditions on Firm Performance," Tinbergen Institute Discussion Papers 08-077/3.

[12] Cappelli P. and Neumark D. (2001), "Do high performance work practices improve establishment-level outcomes?", Industrial and Labor Relations Review, 54(4), $737-775$.

[13] Caroli E. and Van Reenen J. (2001), "Skills and organisational change: evidence from British and French establishment in the 1980s and 1990s", Quarterly Journal of Economics, 116 (4), pp. 1449-1492.

[14] Cristini A., Gaj A., Labory S. and Leoni R. (2003), "Flat Hierarchical Structure, Bundles of New Work Practices and Firm Performance", Rivista Italiana Degli Economisti, 2, 313-341.

[15] Cristini A. (2011), "Employees' motivation and high performance workplace practices", Mimeo, University of Bergamo.

[16] Eriksson, T. (2001), "How Common Are the New Compensation and Work Practices and Who Adopts Them?", Working Paper 01-8, Aarhus School of Business.

[17] Eriksson, T. (2011), Progression of HR Practices in Danish Firms during Two Decades. Working Paper 11-11, Aarhus University, Department of Economics and Business 
[18] Eriksson, T. and V. Smith (2007), "Gavner god ledelse bundlinien? Resultater fra en undersgelse af 1100 danske virksomheder", Ledelse \& Erhvervskonomi, 70, $5-18$

[19] Forth J. and Millward N. (2004), "High Involvement Management and Pay in Britain", Industrial Relations: A Journal of Economy and Society , 43 (1), 98119.

[20] Freeman R. and Medoff J. (1984), What Do Unions Do?, New York: Basic Books.

[21] Freeman R., Kleiner M. and Ostroff C. (2000), "The Anatomy of Employee Involvement and its Effects of Firms and Workers", NBER Working Paper, n.8050.

[22] Godard, J. (2004), "A Critical Assessment of the High-Performance Paradigm", British Journal of Industrial Relations, 42(2), 349-378.

[23] Godard, J. (2007), "Unions, Work Practices, and Wages under Different Institutional Environments: The Case of Canada and England," Industrial and Labor Relations Review, 60(4), 457-476.

[24] Greenan N. and Mairesse J. (1999), "Organisational Change in French Manufacturing: What Do We Learn from Firm Representatives and from Their Employees?", NBER Working Paper n. 7287.

[25] Handel M. and Gittleman M. (2004), "Is there a Wage Payoff to Innovative Work Practices?", Industrial Relations: A Journal of Economy and Society, 43(1), 6797.

[26] Handel, M. and Levine D. (2004) "Editors' Introduction: The Effects of New Work Practices on Workers", Industrial Relations: A Journal of Economy and Society, $43(1), 1-43$. 
[27] Ichniowski C., Shaw K., Prennushi G., (1997), "The Effects of HRM Systems on Productivity: A Study of Steel Finishing Lines", American Economic Review, 87(1), 291-313.

[28] Kalmi, P. and A. Kauhanen (2008), "Workplace Innovations and Employee Outcomes: Evidence from Finland", Industrial Relations: A Journal of Economy and Society, 47 (3), 430-459

[29] Levinsohn J. and Petrin A. (2003), "Estimating Production Functions Using Inputs to Control for Unobservables", Review of Economic Studies, 70(2), 317-341.

[30] Machin S. and Wood S. (2005), "Human Resource Management as a Substitute for Trade Unions in British Workplaces," Industrial and Labor Relations Review, 58(2), 201-218.

[31] Nickell, S., Nicolitsas, D. and Dryden, N. (1997), "What Makes Firms Perform Well?," European Economic Review, 41(3-5), 783-796.

[32] Olley S. and Pakes A. (1996), "The Dynamics of Productivity in the Telecommunications Equipment Industry," Econometrica, 64(1), 1263-1297.

[33] Osterman P., (1994), "How Common is Workplace Transformation and Who Adopts It?," Industrial and Labor Relations Review, 47(2), 173-188.

[34] Osterman, P. (2000), "Work Reorganization in an Era of Restructuring: Diffusion and Effects on Employee Welfare", Industrial and Labor Relations Review, 53, 179- 96.

[35] Osterman, P. (2006), "The Wage Effects of High Performance Work Organization in Manufacturing", Industrial and Labor Relations Review, 59(2), 187-204.

[36] Paauwe, J. and Boselie, P. (2005), "HRM and Performance: What Next?", Human 
Resource Management Journal, 15(4), 68-83.

[37] Parrotta, P. and Pozzoli, D. (2012), "The Effects of Learning-by-Hiring on Productivity", The RAND Journal of Economics, RAND Corporation, 43(1), 167-185.

[38] Rajan, R.G. and J. Wulf (2010), The Flattening Firm: Evidence from Panel Data on the Changing Nature of Corporate Hierarchies. NBER Working Paper 9633.

[39] Westergaard-Nielsen (2001), "20 Years of Labour Market Policies in Denmark", in S.Ilmakunnas and E. Koskela (eds.), Labour Market Institutions and Employment. VATT Publishers, Helsinki.

[40] Wooldridge, J.M. (2009), "On Estimating Firm-level Production Functions Using Proxy Variables to Control for Unobservables", Economics Letters, 104 (1), 112114.

[41] Wood, S. and Wall, T. (2007), "Work Enrichment and Employee Voice in Human Resource Management-Performance Studies", International Journal of Human Resource Management, 18 (7), 1335-1372.

[42] Zwick T. and Kuckulenz A. (2004), "Heterogeneous Returns to Training in Personal Services," Working Papers of the Research Group Heterogenous Labor 04-10, Research Group Heterogeneous Labor, University of Konstanz/ZEW Mannheim. 


\section{A Appendix A: Questions used to defined work- place practices}

The measure of work practices adopted in the survey questionnaire is whether a firm has implemented one of 8 work designs

1. Self-managed teams: an organisation with self-managed teams gives its members authority over how to perform tasks, or even which tasks to perform. Important aspects of team working are pooling of skills and skills development of individual workers.

2. Job rotation: is a system where the workers are explicitly required to rotate between different jobs. This increases the variety of tasks to be performed by the employee and is also likely to enhance the employees understanding of the operation.

3. Quality circles: groups of workers who meet regularly to solve problems concerning productivity and people and to discuss aspects of performance and quality.

4. Total quality management (TQM): an important element of TQM programmes, of which ISO9000 probably is the best known, is that they include employee involvement.

5. Benchmarking: is a formal system of learning about practices in other firms and organisations.

6. Project organisation: Groups of workers are organised in projects with defined targets, timetables, budgets and frequently considerable authority with respect to how to perform tasks.

7. Training: it refers to whether any new appointed employee receives a certain 
amount of informal induction training before being able to handle his/her job in the expected manner.

8. Financial participation schemes: it refers to whether performance related pay structures (team bonus, individual bonus, employee shares, profit sharing and skill-related pay) are applied to the employees (managers, middle managers, salaried workers). 


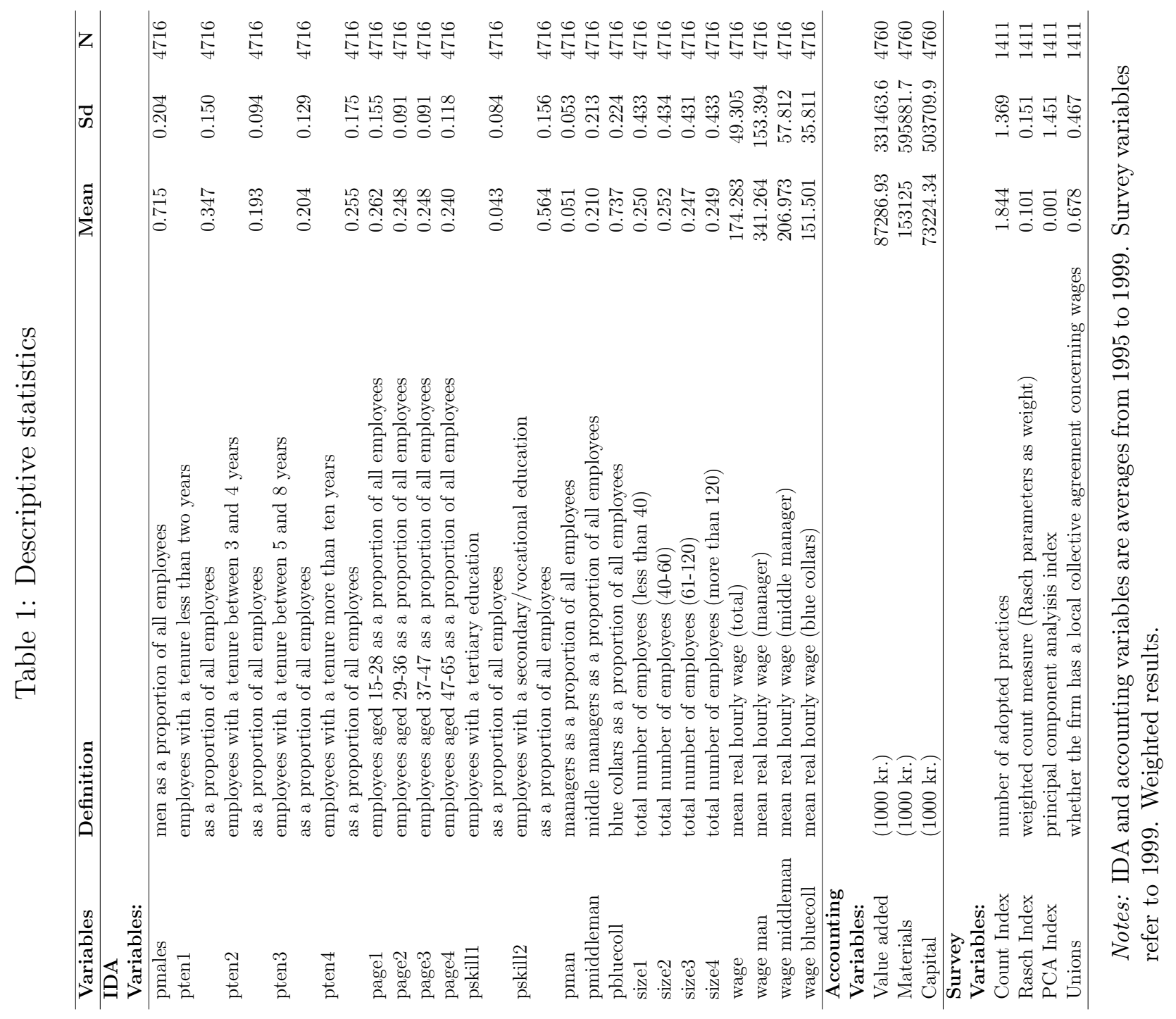


Table 2: Incidence and distribution of workplace practices.

\begin{tabular}{lcccc}
\hline Workplace practices & \% of Firms & \multicolumn{3}{c}{ Years in } \\
& & $1-2$ & $3-6$ & $>6$ \\
\hline Project organization & 14.66 & 3.70 & 3.85 & 7.11 \\
Benchmarking & 3.77 & 1.33 & 1.48 & 0.96 \\
Self-managed team & 21.54 & 6.37 & 6.29 & 8.88 \\
Quality circles & 2.60 & 0.52 & 0.67 & 1.41 \\
Job rotation & 12.95 & 2.96 & 4.44 & 5.55 \\
Total quality management & 4.52 & 1.33 & 2.81 & 1.41 \\
Financial participation schemes & 55.01 & - & - & - \\
Training & 68.12 & - & - & - \\
\hline
\end{tabular}

Notes: Weighted results.

Table 3: Mean of employee outcomes and value added by number of practices adopted.

\begin{tabular}{|c|c|c|c|c|}
\hline \multirow[t]{2}{*}{ Outcomes } & \multicolumn{4}{|c|}{ Number of practices adopted } \\
\hline & 0 & $1-2$ & $3-4$ & $>4$ \\
\hline \multicolumn{5}{|l|}{ Wages } \\
\hline $\log ($ avg hourly wage $)$, total & 5.097 & 5.143 & 5.164 & 5.118 \\
\hline $\log ($ avg hourly wage), managers & 5.622 & 5.767 & 5.804 & 5.821 \\
\hline $\log ($ avg hourly wage), middle managers & 5.254 & 5.290 & 5.319 & 5.278 \\
\hline $\log ($ avg hourly wage $)$, blue collars & 4.996 & 5.005 & 5.010 & 5.001 \\
\hline \multicolumn{5}{|l|}{ Wage inequality } \\
\hline $\log ($ avg wage manager $) / \log$ (avg wage blue collars) & 0.626 & 0.762 & 0.794 & 0.810 \\
\hline $\log (90$ th percentile $) / \log (50$ th percentile $)$ & 0.839 & 0.842 & 0.819 & 0.767 \\
\hline $\log (90$ th percentile $) / \log (10$ th percentile $)$ & 0.380 & 0.410 & 0.450 & 0.421 \\
\hline $\log (50$ th percentile $) / \log (10$ th percentile $)$ & 0.456 & 0.403 & 0.367 & 0.327 \\
\hline \multicolumn{5}{|l|}{ Firm employment shares } \\
\hline managers as a proportion of all employees & 0.048 & 0.051 & 0.049 & 0.042 \\
\hline middle managers as a proportion of all employees & 0.179 & 0.246 & 0.280 & 0.222 \\
\hline blue collars as a proportion of all employees & 0.773 & 0.704 & 0.736 & 0.672 \\
\hline \multicolumn{5}{|l|}{ Financial performance } \\
\hline $\log ($ value added $)$ & 10.264 & 10.753 & 10.844 & 11.310 \\
\hline $\mathbf{N}$ & 194 & 858 & 289 & 70 \\
\hline
\end{tabular}

Notes: All employee outcomes (wages, wage inequality, employment shares) and value added are expressed as time averages from 1995 to 1999. Weighted results. 
Table 4: The effects of workplace practices on financial performance. One and two steps estimates, 1997-1999.

\begin{tabular}{|c|c|c|c|c|c|}
\hline & \multicolumn{5}{|c|}{ Dependent variable: log of value added } \\
\hline & (1) & $(2)$ & (3) & (4) & (5) \\
\hline & \multicolumn{3}{|c|}{ FIRST STAGE } & \multicolumn{2}{|c|}{ ONE STEP } \\
\hline $\ln L$ & $\begin{array}{c}0.771^{* * *} \\
(0.005)\end{array}$ & & & $\begin{array}{c}0.704^{* * *} \\
(0.024)\end{array}$ & $\begin{array}{c}0.772^{* * *} \\
(0.241)\end{array}$ \\
\hline $\ln K$ & $\begin{array}{c}0.088^{* * *} \\
(0.002)\end{array}$ & & & $\begin{array}{c}0.115^{* * *} \\
(0.017)\end{array}$ & $\begin{array}{c}0.105^{* * *} \\
(0.040)\end{array}$ \\
\hline share of males & $\begin{array}{c}0.191^{* * *} \\
(0.007)\end{array}$ & & & $\begin{array}{l}0.111^{*} \\
(0.052)\end{array}$ & $\begin{array}{c}0.148 \\
(0.268)\end{array}$ \\
\hline tenure1 & $\begin{array}{c}-0.603^{* * *} \\
(0.015)\end{array}$ & & & $\begin{array}{c}-0.203^{* * * *} \\
(0.015)\end{array}$ & $\begin{array}{c}-0.201^{* * * *} \\
(0.015)\end{array}$ \\
\hline tenure 2 & $\begin{array}{c}-0.289^{* * *} \\
(0.015)\end{array}$ & & & $\begin{array}{c}-0.129^{* * *} \\
(0.015)\end{array}$ & $\begin{array}{c}-0.123^{* * *} \\
(0.014)\end{array}$ \\
\hline tenure3 & $\begin{array}{l}-0.006 \\
(0.016)\end{array}$ & & & $\begin{array}{c}-0.059^{* * *} \\
(0.014)\end{array}$ & $\begin{array}{l}-0.055 \\
(0.027)\end{array}$ \\
\hline tertiary education & $\begin{array}{c}0.286^{* * *} \\
(0.027)\end{array}$ & & & $\begin{array}{c}0.834^{* *} \\
(0.328)\end{array}$ & $\begin{array}{c}0.701^{* * *} \\
(0.273)\end{array}$ \\
\hline secondary education & $\begin{array}{c}0.181^{* * *} \\
(0.008)\end{array}$ & & & $\begin{array}{c}0.023 \\
(0.020)\end{array}$ & $\begin{array}{c}0.418 \\
(0.541)\end{array}$ \\
\hline share of middle managers & $\begin{array}{c}0.320^{* * *} \\
(0.011)\end{array}$ & & & $\begin{array}{c}0.279^{* * *} \\
(0.054)\end{array}$ & $\begin{array}{c}0.103 \\
(0.529)\end{array}$ \\
\hline share of managers & $\begin{array}{c}0.198^{* * *} \\
(0.022)\end{array}$ & & & $\begin{array}{c}0.230^{* * *} \\
(0.069)\end{array}$ & $\begin{array}{c}0.624 \\
(1.222)\end{array}$ \\
\hline multi-establishment & $\begin{array}{c}0.020^{* * *} \\
(0.005)\end{array}$ & & & $\begin{array}{c}0.276 \\
(0.197)\end{array}$ & $\begin{array}{c}0.140 \\
(0.110)\end{array}$ \\
\hline foreign ownership & $\begin{array}{c}0.190^{* * *} \\
(0.039)\end{array}$ & & & $\begin{array}{l}0.215^{*} \\
(0.114)\end{array}$ & $\begin{array}{c}0.123 \\
(0.114)\end{array}$ \\
\hline firm age & $\begin{array}{l}-0.000 \\
(0.000)\end{array}$ & & & $\begin{array}{r}-0.002 \\
(0.001) \\
\end{array}$ & $\begin{array}{c}0.001 \\
(0.001)\end{array}$ \\
\hline $\begin{array}{l}\mathrm{N} \\
\mathrm{R} 2\end{array}$ & $\begin{array}{l}3069 \\
0.88\end{array}$ & & & & \\
\hline & SECON & D STAG & E, OLS & & \\
\hline count index & $\begin{array}{c}0.119^{* * *} \\
(0.022)\end{array}$ & $\begin{array}{c}0.098^{* *} \\
(0.045)\end{array}$ & & $\begin{array}{c}0.002 \\
(0.007)\end{array}$ & \\
\hline unions & $\begin{array}{c}0.218^{* * *} \\
(0.062)\end{array}$ & $\begin{array}{c}0.168^{*} \\
(0.096)\end{array}$ & $\begin{array}{c}0.220^{* * *} \\
(0.081)\end{array}$ & & \\
\hline unions $\mathrm{x}$ count Index & & $\begin{array}{c}0.028 \\
(0.050)\end{array}$ & & & \\
\hline benchmarking & & & $\begin{array}{c}0.698^{* * *} \\
(0.165)\end{array}$ & & $\begin{array}{c}0.198 \\
(0.233)\end{array}$ \\
\hline self-managed team & & & $\begin{array}{c}-0.197^{*} \\
(0.082)\end{array}$ & & $\begin{array}{l}-0.023 \\
(0.112)\end{array}$ \\
\hline quality circles & & & $\begin{array}{l}-0.197 \\
(0.141)\end{array}$ & & $\begin{array}{c}-0.432 \\
(0.324)\end{array}$ \\
\hline job rotation & & & $\begin{array}{c}0.277^{* * * *} \\
(0.087)\end{array}$ & & $\begin{array}{c}0.145 \\
(0.179)\end{array}$ \\
\hline total quality management & & & $\begin{array}{c}0.071 \\
(0.152)\end{array}$ & & $\begin{array}{c}-0.031 \\
(0.125)\end{array}$ \\
\hline financial participation schemes & & & $\begin{array}{c}0.363^{* * *} \\
(0.050)\end{array}$ & & \\
\hline training & & & $\begin{array}{c}-0.112^{*} \\
(0.056)\end{array}$ & & \\
\hline project organization & & & $\begin{array}{c}0.187^{* * *} \\
(0.060)\end{array}$ & & $\begin{array}{c}0.221 \\
(0.132)\end{array}$ \\
\hline $\mathrm{N}$ & 1349 & 1349 & 1349 & 3069 & 3069 \\
\hline $\mathrm{R} 2$ & 0.08 & 0.08 & 0.14 & 0.91 & 0.91 \\
\hline
\end{tabular}

Notes: Top panel, the dependent variable is the log of value added and all estimates are based on the Wooldridge (2009) approach. Specifications inclus a cos caf the, training and financial participation. Weighted results. *Statistically significant at the 0.10 level, **at the 0.05 level, ***at the 0.01 level. 
Table 5: The effects of workplace practices on financial performance. One and two steps estimates, 1995-1999.

\begin{tabular}{|c|c|c|c|c|c|}
\hline & \multicolumn{5}{|c|}{ Dependent variable: log of value added } \\
\hline & (1) & $(2)$ & $(3)$ & $(4)$ & $(5)$ \\
\hline & \multicolumn{3}{|c|}{ FIRST STAGE } & \multicolumn{2}{|c|}{ ONE STEP } \\
\hline $\ln \mathrm{L}$ & $\begin{array}{c}0.776^{* * *} \\
(0.011)\end{array}$ & & & $\begin{array}{c}0.729^{* * *} \\
(0.023)\end{array}$ & $\begin{array}{c}0.716^{* * *} \\
(0.042)\end{array}$ \\
\hline $\ln K$ & $\begin{array}{c}0.103^{* * *} \\
(0.009)\end{array}$ & & & $\begin{array}{c}0.105^{* * *} \\
(0.015)\end{array}$ & $\begin{array}{c}0.118^{* * *} \\
(0.022)\end{array}$ \\
\hline share of males & $\begin{array}{c}0.243^{* * *} \\
(0.017)\end{array}$ & & & $\begin{array}{c}0.066 \\
(0.048)\end{array}$ & $\begin{array}{c}0.120 \\
(0.079)\end{array}$ \\
\hline tenure 1 & $\begin{array}{c}-0.879 * * * \\
(0.034)\end{array}$ & & & $\begin{array}{c}-0.898^{* * *} \\
(0.104)\end{array}$ & $\begin{array}{c}-0.598^{* * *} \\
(0.104)\end{array}$ \\
\hline tenure2 & $\begin{array}{c}-0.512^{* * * *} \\
(0.038)\end{array}$ & & & $\begin{array}{c}-0.610^{* * *} \\
(0.115)\end{array}$ & $\begin{array}{c}-0.210^{*} \\
(0.115)\end{array}$ \\
\hline tenure3 & $\begin{array}{c}-0.082^{* *} \\
(0.040)\end{array}$ & & & $\begin{array}{l}-0.128 \\
(0.112)\end{array}$ & $\begin{array}{c}-0.178^{*} \\
(0.092)\end{array}$ \\
\hline tertiary education & $\begin{array}{c}0.440^{* * * *} \\
(0.122)\end{array}$ & & & $\begin{array}{c}0.768^{* *} \\
(0.312)\end{array}$ & $\begin{array}{l}0.774^{*} \\
(0.437)\end{array}$ \\
\hline secondary education & $\begin{array}{c}0.168^{* * *} \\
(0.017)\end{array}$ & & & $\begin{array}{c}0.211^{* * *} \\
(0.051)\end{array}$ & $\begin{array}{c}0.292^{* * *} * \\
(0.073)\end{array}$ \\
\hline share of middle managers & $\begin{array}{c}0.284^{* * *} \\
(0.030)\end{array}$ & & & $\begin{array}{c}0.228^{* * *} \\
(0.062)\end{array}$ & $\begin{array}{c}0.244^{* * *} \\
(0.091)\end{array}$ \\
\hline share of managers & $\begin{array}{c}0.227^{* * *} \\
(0.047)\end{array}$ & & & $\begin{array}{c}0.233 \\
(0.178)\end{array}$ & $\begin{array}{c}0.283 \\
(0.206)\end{array}$ \\
\hline multi-establishment & $\begin{array}{c}0.017^{* *} \\
(0.008)\end{array}$ & & & $\begin{array}{c}0.045^{* *} \\
(0.018)\end{array}$ & $\begin{array}{c}0.034 \\
(0.031)\end{array}$ \\
\hline foreign ownership & $\begin{array}{c}0.002 \\
(0.064)\end{array}$ & & & $\begin{array}{l}0.156^{*} \\
(0.079)\end{array}$ & $\begin{array}{l}0.143^{*} \\
(0.079)\end{array}$ \\
\hline firm age & $\begin{array}{c}-0.003^{* * *} \\
(0.001)\end{array}$ & & & $\begin{array}{l}-0.004 \\
(0.003)\end{array}$ & $\begin{array}{l}-0.001 \\
(0.002)\end{array}$ \\
\hline $\begin{array}{l}\mathrm{N} \\
\mathrm{R} 2\end{array}$ & $\begin{array}{l}5643 \\
0.89\end{array}$ & & & & \\
\hline & SECOI & D STAC & E, OLS & & \\
\hline count index & $\begin{array}{c}0.119^{* * *} \\
(0.022)\end{array}$ & $\begin{array}{c}0.098^{* *} \\
(0.045)\end{array}$ & & $\begin{array}{c}0.005 \\
(0.004)\end{array}$ & \\
\hline unions & $\begin{array}{c}0.218^{* * *} \\
(0.062)\end{array}$ & $\begin{array}{l}0.167^{*} \\
(0.097)\end{array}$ & $\begin{array}{c}0.187^{* * *} \\
(0.060)\end{array}$ & & \\
\hline unions $\mathrm{x}$ count Index & & $\begin{array}{c}0.028 \\
(0.051)\end{array}$ & & & \\
\hline benchmarking & & & $\begin{array}{c}0.219^{* * *} \\
(0.081)\end{array}$ & & $\begin{array}{c}0.175 \\
(0.209)\end{array}$ \\
\hline self-managed team & & & $\begin{array}{c}0.697^{* * *} \\
(0.165)\end{array}$ & & $\begin{array}{l}-0.021 \\
(0.102)\end{array}$ \\
\hline quality circles & & & $\begin{array}{c}-0.197^{* * * *} \\
(0.062)\end{array}$ & & $\begin{array}{l}-0.411 \\
(0.315)\end{array}$ \\
\hline job rotation & & & $\begin{array}{l}-0.197 \\
(0.140)\end{array}$ & & $\begin{array}{c}0.098 \\
(0.219)\end{array}$ \\
\hline total quality management & & & $\begin{array}{c}0.277^{* * *} \\
(0.087)\end{array}$ & & $\begin{array}{c}0.061 \\
(0.111)\end{array}$ \\
\hline financial participation schemes & & & $\begin{array}{c}0.071 \\
(0.152)\end{array}$ & & \\
\hline training & & & $\begin{array}{c}0.365^{* * *} \\
(0.050)\end{array}$ & & \\
\hline project organization & & & $\begin{array}{c}-0.111^{* *} \\
(0.053)\end{array}$ & & $\begin{array}{c}0.201 \\
(0.111)\end{array}$ \\
\hline $\mathrm{N}$ & 1349 & 1349 & 1349 & 5643 & 5643 \\
\hline $\mathrm{R} 2$ & 0.08 & 0.08 & 0.14 & 0.91 & 0.91 \\
\hline
\end{tabular}

Notes: Top panel, the dependent variable is the log of value added and all estimates are based on the Wooldridge (2009) approach. Specifications include a constant term, a polynomial function of capital, the share of differently aged workers belonging to the employeesage distribution quartiles, materials and labour, regional, size, year and industry dummies. Lower panel, columns (1)-(3) report the results of three specification of the second step regression and also include a constant term, regional, size and industry dummies. Column 4, the count index excludes training and financial participation. Weighted results. *Statistically significant at the 0.10 level, **at the 0.05 level, ***at the 0.01 level. 


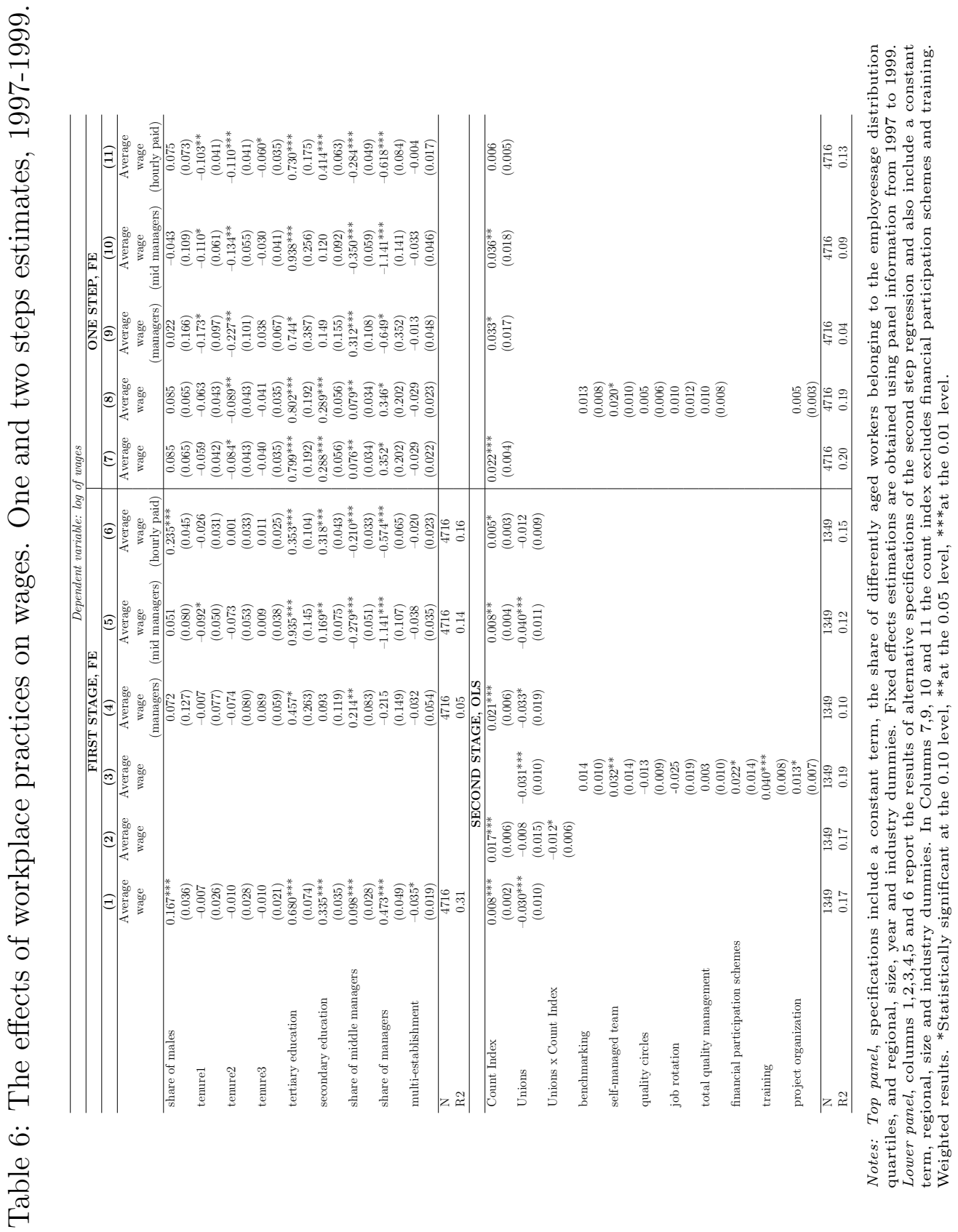




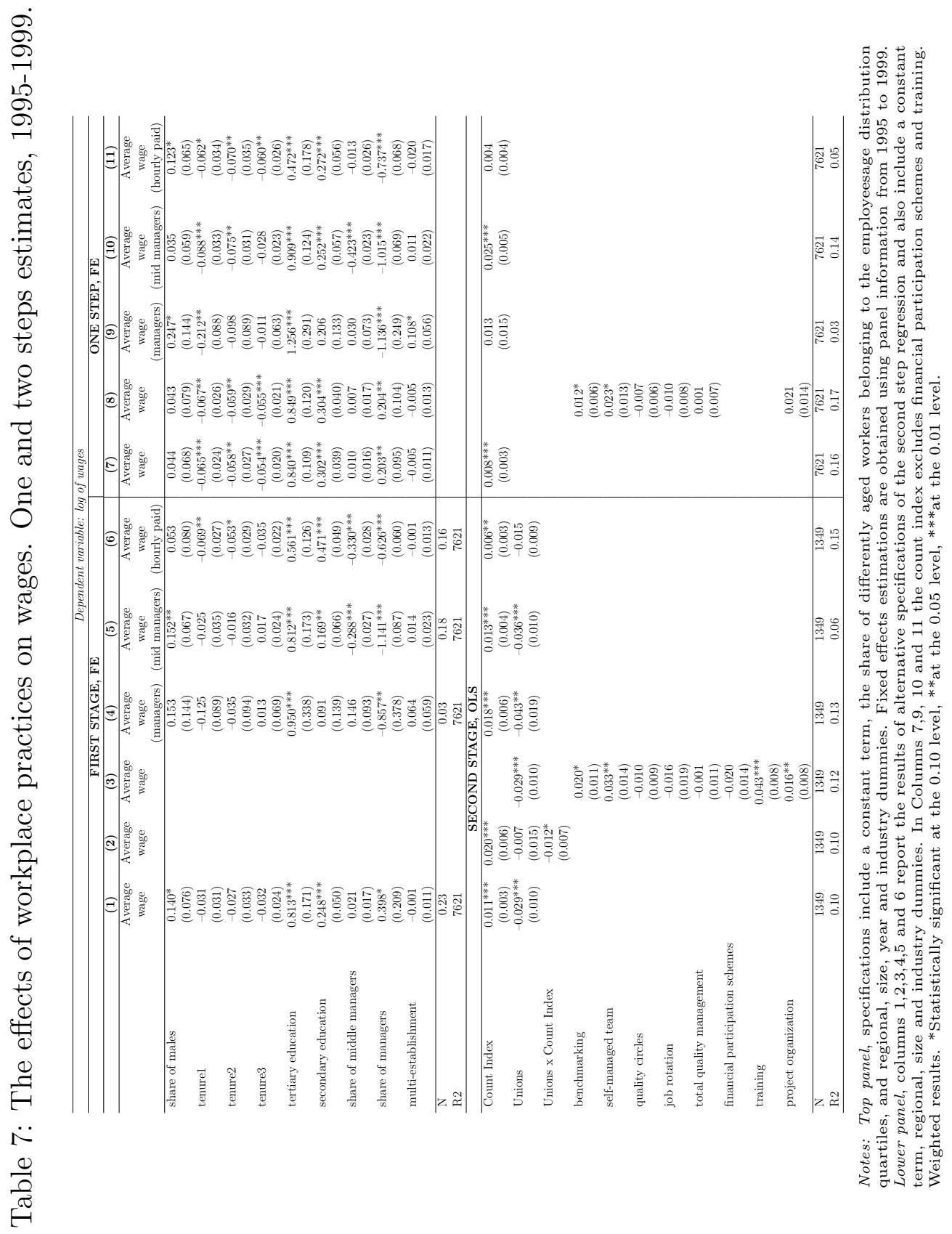




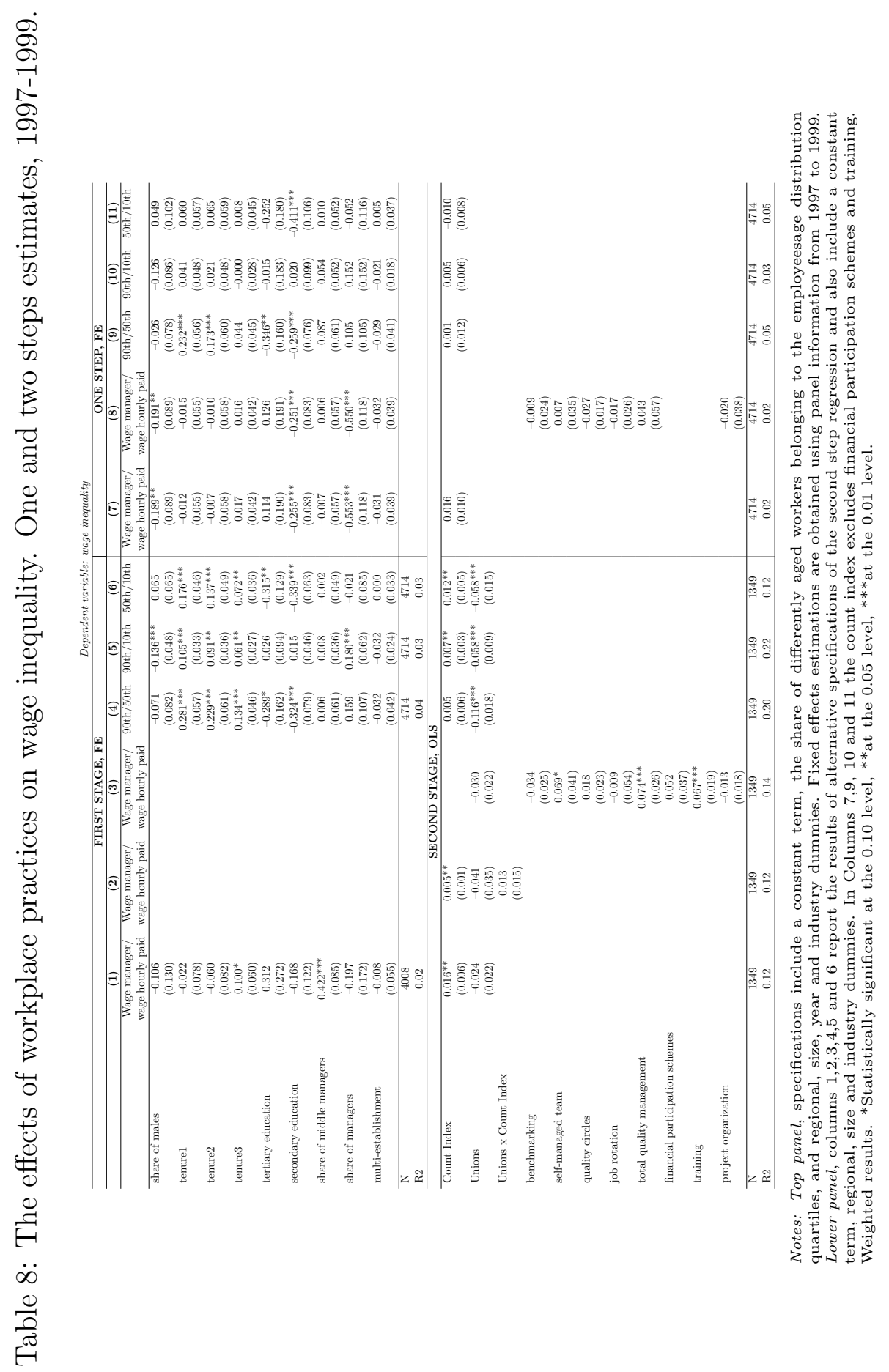




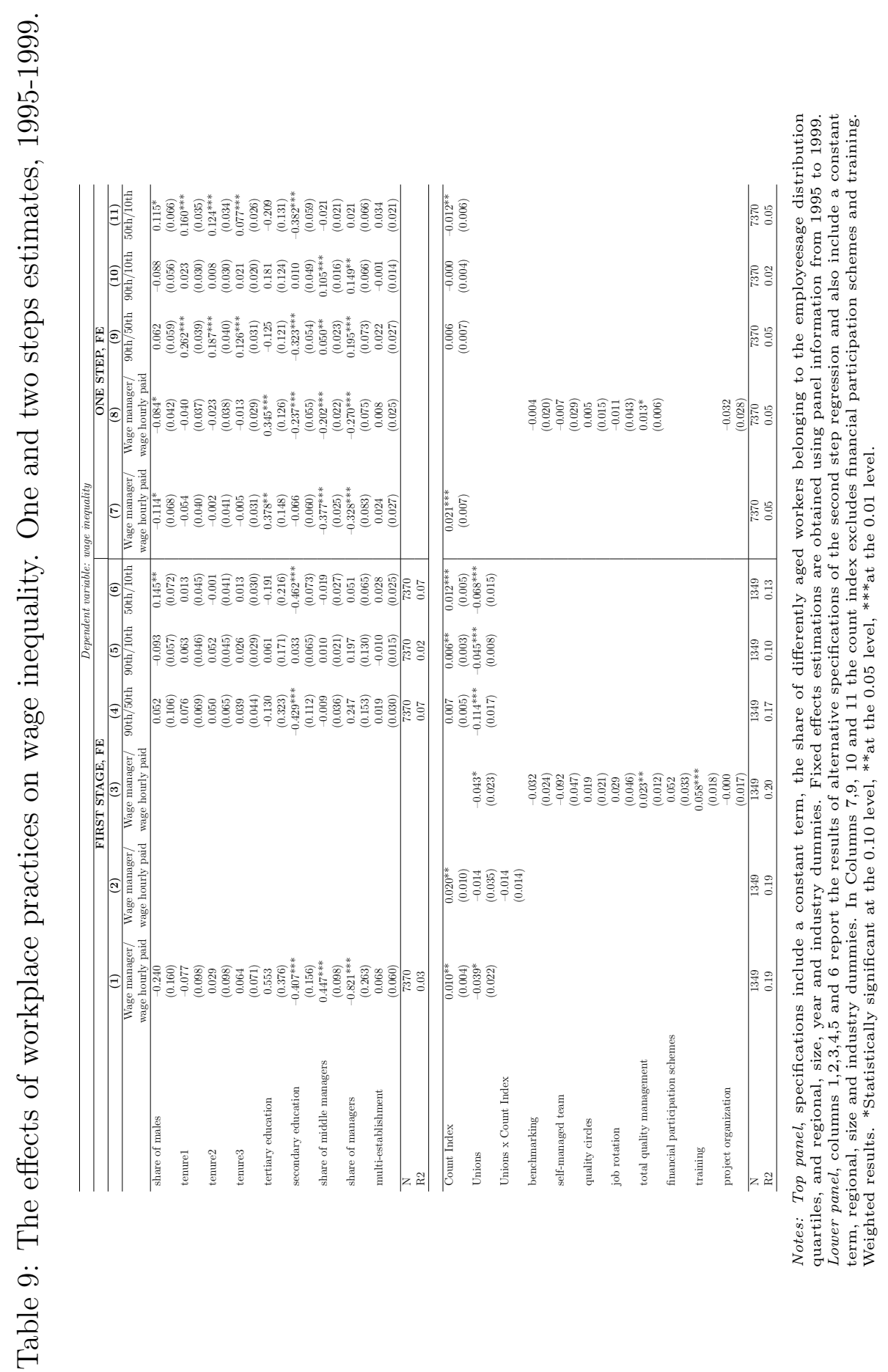




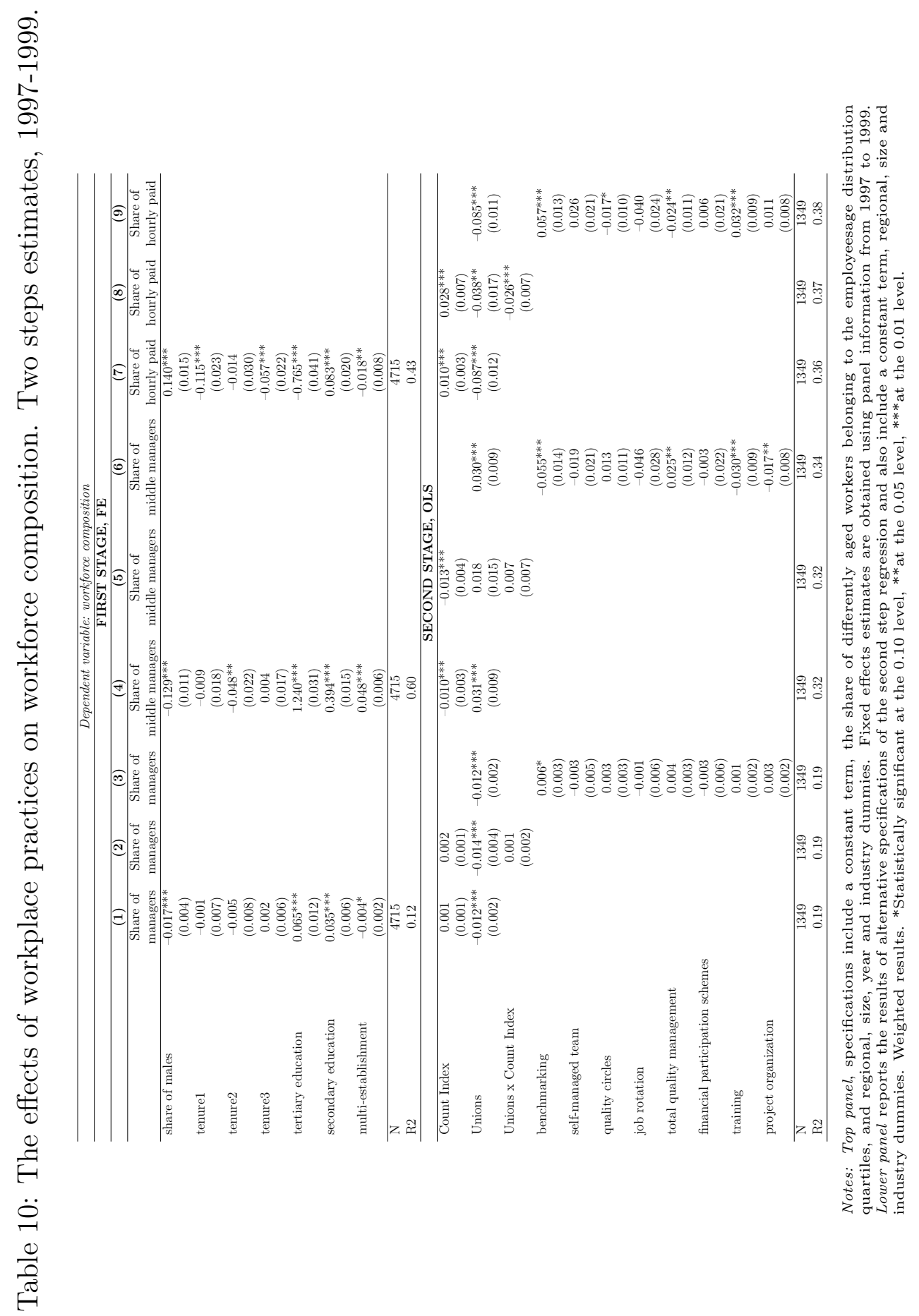




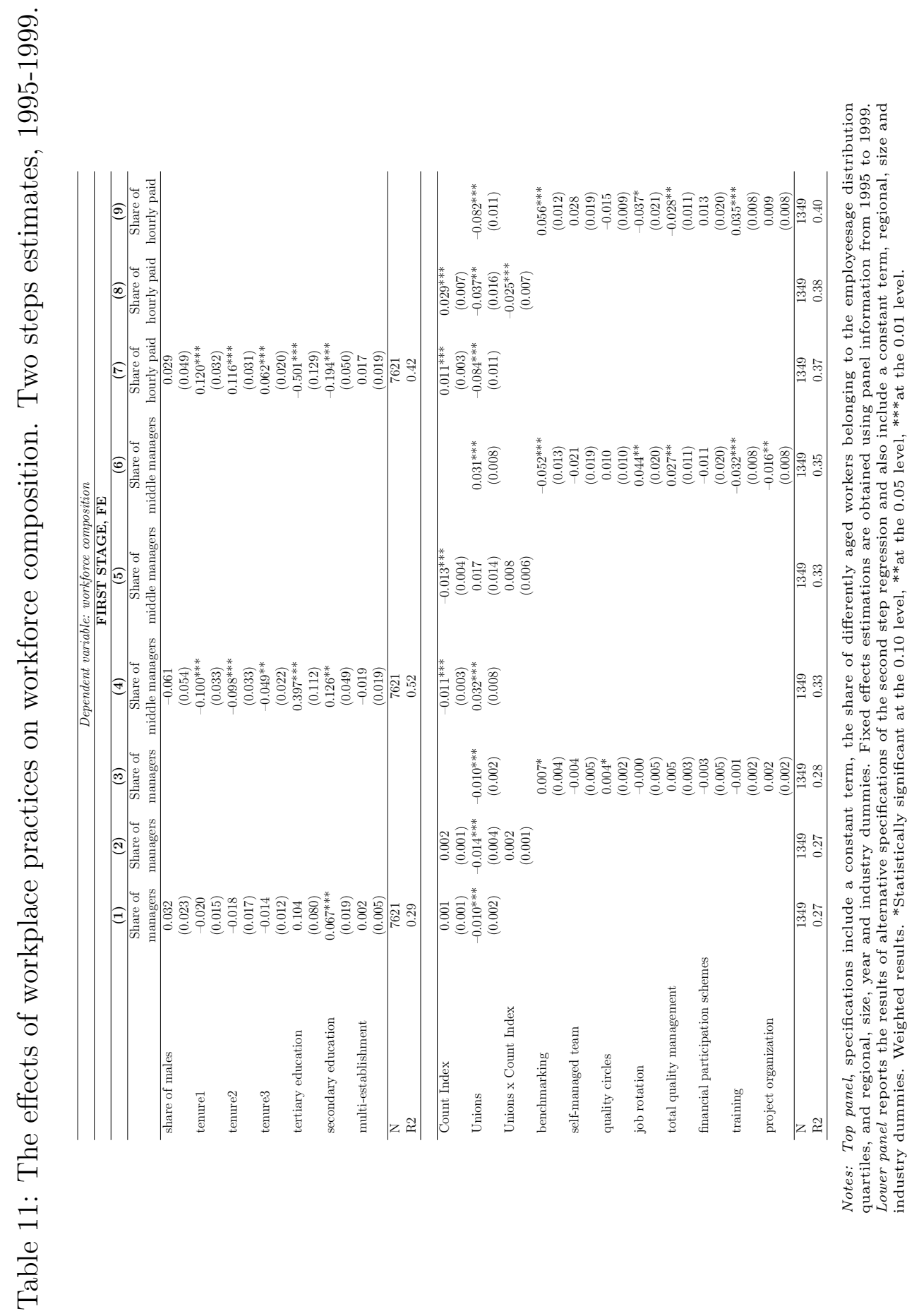




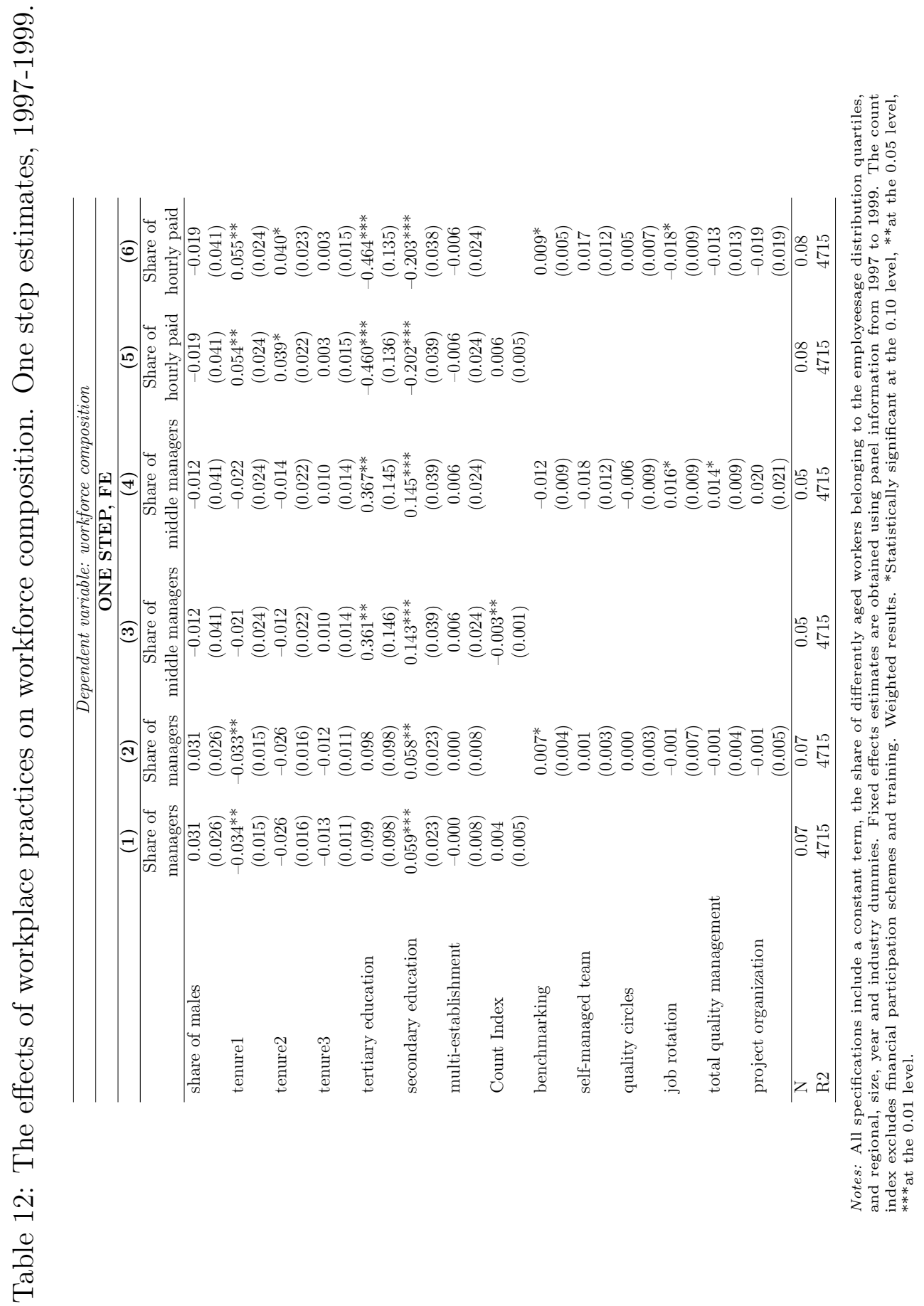




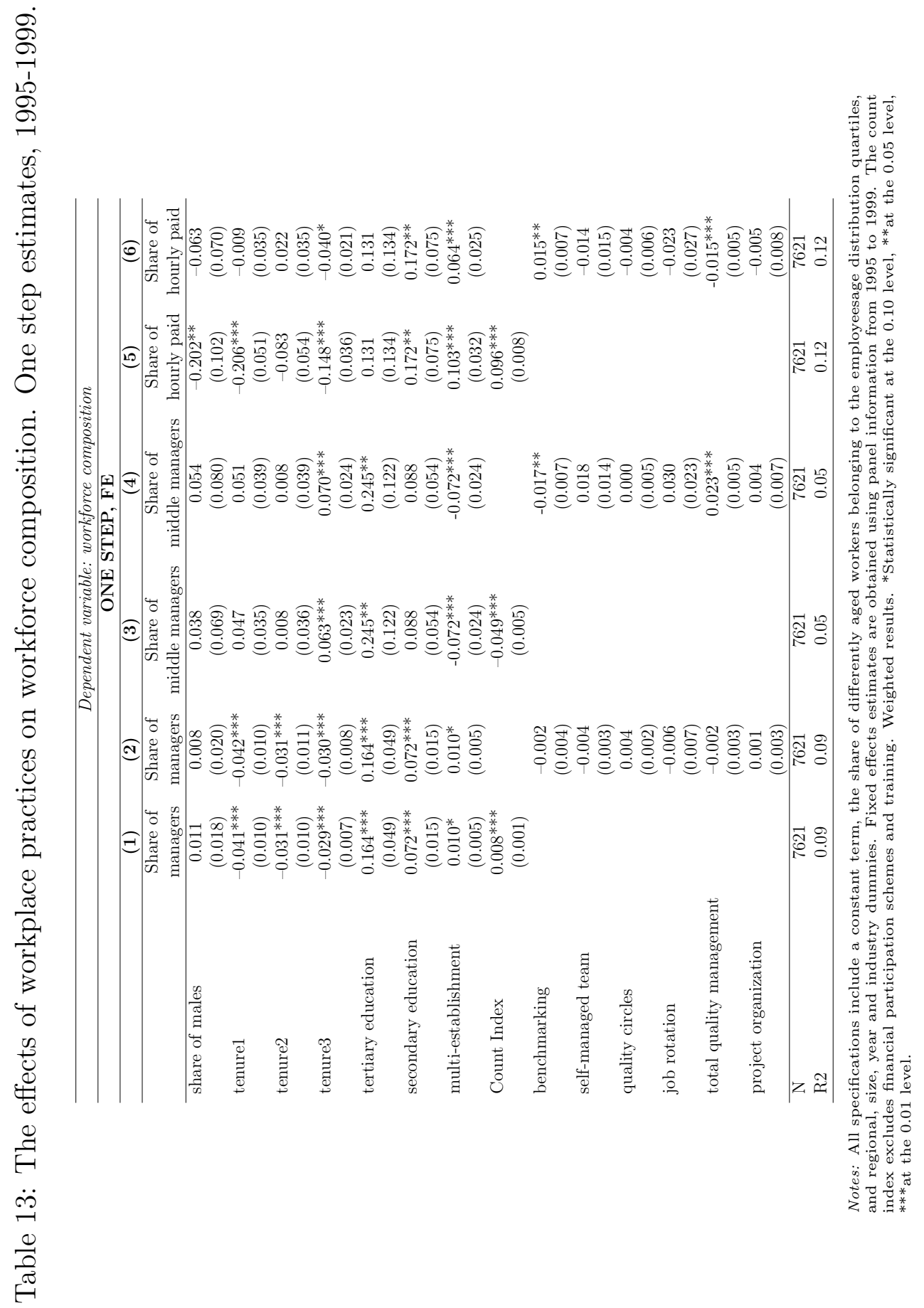

